\title{
Screening of $\beta$-thalassemia trait and other hemoglobinopathies among blood donors in Punjab
}

Introduction: Hemoglobinopathies are common genetic disorders of hemoglobin, which can be prevented by population screening and offering genetic counseling. The cumulative gene frequency of hemoglobinopathies in India is $4.2 \%$. The carrier state for $\beta$-thalassemia in India varies from $1 \%$ to $17 \%$ with an average of $3.2 \%$. The present study was undertaken to find out the burden of hemoglobinopathies and spectrum of this disorders among the blood donors. Materials and Methods: The study includes 975 students between 18 and 25 years who donated blood, were screened for $\beta$-thalassemia trait and related hemoglobinopathies by highperformance liquid chromatography (HPLC) using Bio-Rad variant. Samples were also run on a hemato analyzer for red cell indices and peripheral smear for red cell morphology. Results: A total of 41 donors showed abnormal hemoglobin fractions in HPLC. Out of these, $32(3.3 \%)$ were diagnosed with $\beta$-thalassemia trait, $8(0.8 \%)$ with $\mathrm{Hb}-\mathrm{D}$ Punjab and $1(0.1 \%)$ with $\mathrm{Hb}-\mathrm{S}$ trait. The frequency of $\beta$-thalassemia trait in the student from different geographical regions varied from $0.8 \%$ to $4.44 \%$, being the highest in those from Punjab and frequency of $\beta$-thalassemia trait in different caste groups varied from 0 to $4.74 \%$, being the highest in the student from Jatt Sikh community. Conclusions: A universal approach of screening for $\beta$-thalassemia trait should be included as a part of standard blood testing among the college students, premarital and of the extended family of thalassemics. Population group with high gene frequencies requires screening programs as well as increased awareness and education program to control the birth of thalassemia major.

Rajesh Kumar, Sonia Gupta, Aikaj Jindal, Shruti Kakkar', Amarjit Kaur

Department of ImmunoHematology and Blood Transfusion, ${ }^{1}$ Paediatrics, Dayanand Medical College and Hospital, Ludhiana, Punjab, India

Address for the Correspondence: Dr. Rajesh Kumar, 9942/1, Joshi Nagar, Ludhiana - 141001 , Punjab, India. parul_pulkit@yahoo.co.in

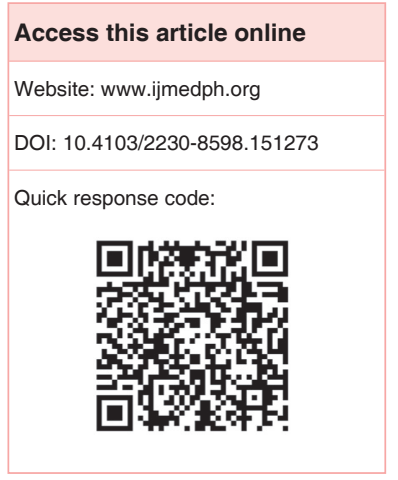

Key words: Blood donor, hemoglobinopathies, high performance liquid chromatography, $\beta$-thalassemia trait

\section{INTRODUCTION}

Hemoglobinopathies are common genetic disorders of hemoglobin in which there is an abnormal production or structure of the hemoglobin molecule. These hereditary disorders are major public health problem in many parts of the world including South East Asia like India. The clinical spectrum of these disorders varies from asymptomatic conditions to serious disorders like thalassemia major that requires regular blood transfusions and widespread medical care. ${ }^{[1,2]}$ World Health Organization (WHO) figures estimate that $7 \%$ of the world population is carrier for hemoglobin disorders. ${ }^{[3]}$ The cumulative gene frequency of hemoglobinopathies in India is $4.2 \%$ with a population of over 1.2 billion and over 12,000 infants born each year with a clinically significant hemoglobinopathies. ${ }^{[4,5]}$ The carrier state for b-thalassemia in India varies from $1 \%$ to $17 \%$ with an average of $3.2 \% .{ }^{[6,7]}$ Hemoglobin E- $\beta$-thalassemia and Hb-S (sickle cell anemia) are also a very common problem with high frequency in South East Asia and have been reported from different parts of India. ${ }^{[8,9]}$ Hemoglobin D-Punjab is one of the most commonly encountered abnormal hemoglobins worldwide. ${ }^{[10]}$ It is present in a large number of people in Pakistan and North-West India and has a high frequency in Punjab with an incidence of $2-3 \% .^{[11,12]}$

India is a vast country with considerable regional and ethnic heterogeneity; various studies are being conducted in evaluating the prevalence of thalassemia trait and hemoglobinopathies in various 
regions. Patients homozygous for $\beta$-thalassemia usually present with symptoms of the disease, whereas carriers for $\beta$-thalassemia trait can have varying degrees of anemia while some of them may have no symptoms. They are usually detected during examination of the relatives of severely affected patients as part of screening programs or during the investigation of mild iron refractory hypochromic anemia. $^{[13]}$

Accurate and timely screening of various $\mathrm{Hb}$ variants including $\beta$-thalassemia traits before marriages of couples at risk and prenatal diagnosis can prevent the occurrence of more serious disorders like thalassemia major in newborns substantially. ${ }^{[14]}$ Prospective prevention through population screening and genetic counseling is the best possible strategy in the prevention of these disorders. As the exact data pertaining to the prevalence of hemoglobinopathies in this region is scarce, we consider that it is important to find out the extent of burden of hemoglobinopathies in this region.

The aim of study was to find out the prevalence of $\beta$-thalassemia trait and other hemoglobinopathies in blood donors.

\section{MATERIALS AND METHODS}

The present study attempted to find out the prevalence of $\beta$-thalassemia trait and other hemoglobinopathies in the blood donor population screened during the period from September 2013 to March 2014 in the Department of Immunohematology and Blood Transfusion. An attempt was made to spread the awareness about importance of thalassemia trait testing before marriage among donors. A total of 975 students of Punjab Agriculture University and Guru Angad Dev Veterinary and Animal Science University, with age group ranging from 18 to 25 years who donated blood were included in the study and screened for various hemoglobinopathies. All the blood donors were from the different geographical region like Punjab, Haryana, Himchal Pradesh and Jammu Kashmir. Samples were run on LH 750 analyzer (Beckman Coulter) for red Cell indices, and peripheral smear for red cell morphology were analyzed. The samples having mean corpuscular volume (MCV) $\leq 76 \mathrm{fl}$ and mean corpuscular hemoglobin $(\mathrm{MCH}) \leq 27 \mathrm{pg}$ were further quantified for $\mathrm{HbA}_{2}$ using Bio-Rad "Variant," USA that utilized the principal of highperformance liquid chromatography (HPLC). It is a sensitive and precise method for quantification of $\mathrm{HbA}_{2}, \mathrm{HbF}$ and abnormal hemoglobin fraction. ${ }^{[15]}$

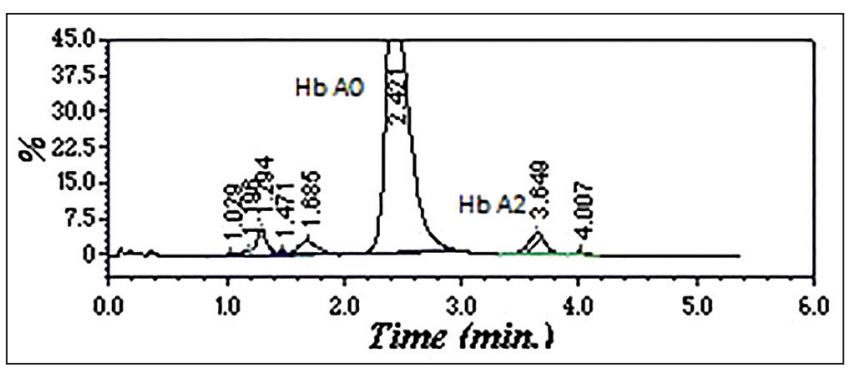

Figure 1: Chromatogram showing beta-thalassemia trait

\section{RESULTS}

A total of 975 blood donors were screened for $\beta$-thalassemia trait and other hemoglobinopathies. It included 830 males and 145 females with ages between 18 and 25 years. The mean age was 22.5 year and male-female ratio is 5.7:1. Of these, $41(4.2 \%)$ donors showed abnormal hemoglobin fraction in HPLC. The major abnormalities observed were of high $\mathrm{Hb}-\mathrm{A}_{2}$ level and a cut-off of $3.5 \%$ was taken for diagnosis of b-thalassemia trait. A total of 32 donors (3.3\%) were diagnosed with b-thalassemia trait. It was found that the majority of blood donors had $\mathrm{Hb} 12.5 \mathrm{~g} \%$ or above including those who tested positive for hemoglobinopathies, but $\mathrm{Hb}-\mathrm{F}$ levels are within normal limits with the variable reduction in $\mathrm{Hb}-\mathrm{A}_{1}$ [Figure 1]. MCV and $\mathrm{MCH}$ were below normal limits with raised RBCs count and serum ferritin levels are within normal limits. Peripheral blood film (PBF) showed mild anisopoikilocytosis and microcytic hypochromic blood picture. Serum ferritin and red cell indices of all the remaining blood donors were within the normal limits.

Eight $(0.8 \%)$ donors showed the presence of Hb-D Punjab trait on HPLC displayed a D window with variant percentage ranging from $30 \%$ to $33 \%$. The blood parameters were essentially normal in these donors [Figure 2]. One donor had high Hb- $\mathrm{A}_{2}$ along with slightly increased $\mathrm{Hb}-\mathrm{S}$, blood picture showed target cells and was diagnosed as Hb-S trait. The diagnosis of Hb-D Punjab or Hb-S trait was not confirmed by molecular testing owing to high cost.

Prevalence of b-thalassemia trait and other hemoglobinopathies (Hb-D Punjab, Hb-S trait) are shown in Table 1. Majority of donors screened were from Punjab (383), Haryana (298), Himachal (175) and Jammu and Kashmir (119). The frequency of the b-thalassemia trait in donors of different states is $0.8 \%$ to $4.44 \%$, being highest $(4.44 \%$ ) in Punjab as shown in Table 2. Students from castes group showed the presence of $\beta$-thalassemia trait with a frequency ranging from $0 \%$ to $4.74 \%$, being highest $(4.74 \%)$ in Jatt Sikh as shown in Table 3.

\section{DISCUSSION}

HPLC is considered as one of the best methods for screening and detection of various hemoglobinopathies with rapid, reproducible and precise results. It is recommended for detection of $\beta$-thalassemia trait in population and necessary for genetic counseling to reduce the incidence and burden of thalassemia major in the society. ${ }^{[16,17]}$ The present study included predominately students of two universities

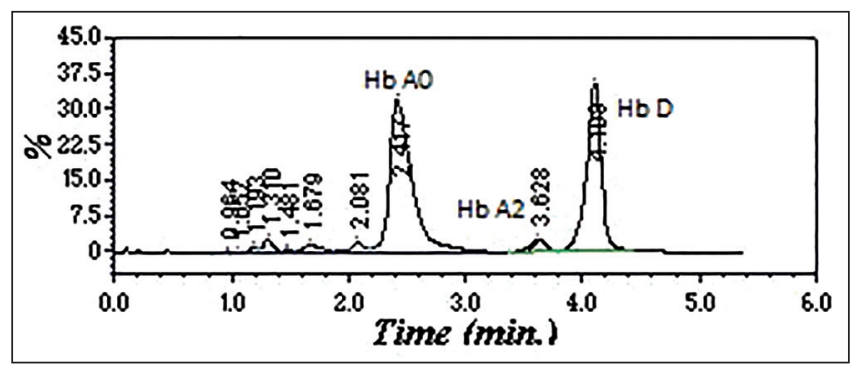

Figure 2: Chromatogram showing $\mathrm{Hb} \mathrm{D}-\mathrm{Punjab}$ 


Table 1: Prevalence of $\beta$-thalassemia trait
\begin{tabular}{lccc} 
and related hemoglobinopathies in blood donors \\
\hline Hemoglobinopathies & $\begin{array}{c}\text { Donors } \\
\text { screened } \\
\text { (Total) }\end{array}$ & $\begin{array}{c}\text { No. of } \\
\text { positive } \\
\text { donors }\end{array}$ & $\begin{array}{c}\text { Percentage } \\
\text { (Total) }\end{array}$ \\
\hline$\beta$-thalassemia trait & 975 & 32 & 3.3 \\
Hb-D Punjab & 975 & 8 & 0.8 \\
Hb-S Trait & 975 & 1 & 0.1 \\
\hline
\end{tabular}

\begin{tabular}{lccc}
$\begin{array}{l}\text { Table 2: Frequency of } \beta \text {-thalassemia trait } \\
\text { in different geographical regions }\end{array}$ & \\
\hline State & $\begin{array}{c}\text { Donors } \\
\text { screened } \\
\text { (Total) }\end{array}$ & $\begin{array}{c}\text { Donors with } \\
\beta \text {-thalassemia } \\
\text { trait }\end{array}$ & $\begin{array}{c}\text { Percentage } \\
\text { (Total) }\end{array}$ \\
\hline Punjab & 383 & 17 & 4.44 \\
Haryana & 298 & 8 & 2.68 \\
Himachal Pradesh & 175 & 5 & 2.86 \\
Jammu and Kashmir & 119 & 1 & 0.8 \\
\hline
\end{tabular}

\begin{tabular}{|c|c|c|c|}
\hline Caste group & $\begin{array}{c}\text { Donors } \\
\text { screened (Total) }\end{array}$ & $\begin{array}{c}\text { Donors with } \\
\beta \text {-thalassemia trait }\end{array}$ & $\begin{array}{c}\text { Percentage } \\
\text { (Total) }\end{array}$ \\
\hline Jatt Sikh & 295 & 14 & 4.74 \\
\hline Jain & 125 & 4 & 3.2 \\
\hline Brahmin & 149 & 3 & 2 \\
\hline Baniya & 120 & 4 & 3.3 \\
\hline Khatri & 136 & 3 & 2.2 \\
\hline Jaat & 120 & 3 & 2.5 \\
\hline Kayastha & 30 & 0 & 0 \\
\hline
\end{tabular}

who donated blood in voluntary blood donation camps; they were considered to be fair representative of all sections of the population and also comprised of that group of population which could be easily accessed for further investigation and counseling. There was in total $4.2 \%$ hemoglobin variant detected, $\beta$-thalassemia trait formed the largest subgroup of abnormal hemoglobin (3.3\%) followed by Hb-D Punjab $(0.8 \%)$ and Hb-S trait $(0.1 \%)$. Majority of the donors were males $(85.12 \%)$ and low percentage of female donors could be due to low weight and anemia that barred them from donating blood. $\beta$-thalassemia trait is probably the most common inherited hemoglobin disorder in the Indian sub-continent. This study on students established that $\beta$-thalassemia trait is the most frequent hemoglobinopathies of clinical importance although it varies considerably in the region and in different caste groups. The incidence was higher in Punjab being $4.44 \%$ in our study as compared to $6.75 \%$ in West Bengal ${ }^{[18]} 5.5 \%$ in Delhi, ${ }^{[19]} 2.8 \%$ in Eastern Uttar Pradesh ${ }^{[20]}$ and $2.7 \%$ in Mumbai. ${ }^{[19]}$ Prevalence rate of $\beta$-thalassemia trait in different caste groups varied from $0 \%$ to $4.74 \%$ in our study. It was $4.74 \%$ in Jatt Sikh, 3.3\% in Baniya, 3.2\% in Jain, $2.5 \%$ in Jatt, $2.2 \%$ in Khatri, and $2.1 \%$ in Brahmin. Similar results have reported a prevalence of $\beta$-thalassemia trait in different caste group as 2.7\% in Baniya, 4.8\% in Jain, 3.8\% in Khatri and 5.3\% in Brahmin. ${ }^{[19]}$ In the neighboring country of Pakistan, the frequency of $\beta$-thalassemia trait has been reported to be $5.6 \%$ similar to our results with a largely Punjabi population. ${ }^{[21]} \mathrm{Hb}-\mathrm{D}$ Punjab $(0.8 \%)$ was seen in students which were Punjabi as compared to $0.08 \%$ in Eastern Uttar Pradesh, ${ }^{[22]} 0.7 \%$ and $1.1 \%$ in Delhi and Mumbai, respectively. ${ }^{[19]} \mathrm{Hb}-\mathrm{S}$ trait $(0.1 \%)$ was seen in a student who belonged to Jammu Kashmir probably due to the greater influx of population from tribal area and present $0.08 \%, 0.2 \%$ and $0 \%$ in Eastern Uttar Pradesh, ${ }^{[22]}$ Mumbai and Delhi. ${ }^{[19]} \mathrm{Hb}-\mathrm{S}$ is more frequently observed in tribal population, $\mathrm{Hb}-\mathrm{E}$ in the eastern region, $\mathrm{Hb}-\mathrm{D}$ in Punjab and $\beta$-thalassemia trait to varying degree in almost all the population groups. However, with the migration of population across the country often for the purpose of employment, likely to be cause of the presence of unexpected hemoglobin in the population. ${ }^{[23,24]}$

Using the overall carrier frequency of $\beta \mathrm{T}^{*} \mathrm{~T}$ of $3.3 \%$ found in this study, the birth incidence of thalassemia can be calculated using the HardyWeinberg equation for recessively inherited single gene disorders. With current estimates of the Indian population being approximately 1.25 billion and a birth rate of $23 / 1000$, the approximate estimate of homozygous births would be 10,879 per year. This gives a fairly accurate assessment of the thalassemic load. The observed incidence in students of different regions and caste groups will permit National Programs for Thalassemia to be planned and carried out with greater precision and assurance. Several Mediterranean and western countries have achieved a significant change in the homozygote population since last two decades after the implementation of Thalassemia Control Programs. ${ }^{[25]}$ However, few antenatal screening programmes are going on but more centre are require to screened the population with follow-up to reduce the birth of $\beta$-thalassemia major.

A universal approach of screening of college students, premarital and of the extended family of thalassemic along with antenatal diagnosis needs to be considered for this vast and ethnically diverse country. Education and awareness regarding thalassemia need to be accelerated urgently among medical practitioners, paramedics, thalassemic and general population to reduce the morbidity and mortality and the financial and socio-psychological burden of the thalassemic families. Extended family screening of thalassemic allows identification of large majority of population at risk by screening only $13 \%$ of the population. ${ }^{[26]}$ It has been estimated that the lifetime cost of healthcare, premature mortality and lost earnings versus a national screening program including antenatal diagnosis in Israel ${ }^{[27]}$ gives a cost-benefit ratio of $4.2: 1$ and adding a societal perspective 6.01:1. A recent report from Hong Kong ${ }^{[28]}$ offers an almost similar cost — benefit ratio.

To conclude, our study had 3.3\% $\beta$-thalassemia trait and early detection of traits will prevent the occurrence of thalassemia major in offsprings. Detection of other variants becomes important due to complex interactions in cases with double heterozygous and homozygous states, which may lead to severe hematological abnormalities. Findings must be supplemented with hemogram findings, family/sibling studies, other confirmatory techniques and molecular studies based on HPLC findings. This is especially important in view of high incidence of $\beta$-thalassemia trait in the Indian subcontinent. Screening for 
thalassemia trait should be included as part of a standard blood testing before blood donation.

\section{REFERENCES}

1. Weatherall DJ, Clegg JB. Inherited haemoglobin disorders: An increasing global health problem. Bull World Health Organ 2001;79:704-12.

2. Fucharoen $\mathrm{S}$, Winichagoon O. Thalassemia in Southeast Asia: Problem and strategy for prevention and control. Southeast Asian J Trop Med Public Health 1992;23:647-55.

3. WHO. Management of Haemoglobin Disorders. Report of Joint WHO-TIF Meeting on the Management of Haemoglobin Disorders. Nicosia, Cyprus, 16-18 November 2007. Geneva: World Health Organization; 2008. p. 1-2.

4. Agarwal MB. The burden of Haemoglobinopathies in India. J Assoc Physicians India 2005;53:1017-8.

5. Dolai TK, Dutta S, Bhattachryya M, Ghosh MK. Prevalence of hemoglobinopathies in rural Bengal, India. Hemoglobin 2012;36:57-63.

6. Vaz FE, Thakur CB, Banerjee MK, Gangal SG. Distribution of $\beta$-Thalassemia mutations in the Indian Population referred to a diagnostic centre. Haemoglobin 2000;24:181-94.

7. Agarwal MB, Mehta BC. Symptomatic $\beta$-Thalassemia trait (A study of 143 cases). J Postgrad Med 1982;28:4-8.

8. Chatterjea JB. Some aspects of Hb-E and its genetic interaction with Thalassemia. Indian J Med Res 1965;53:377-83.

9. Gupta SC, Mehrotra TN, Mehrotra VG. Hb-E thalassemias in Uttar Pradesh. Indian J Med Res 1970;58:857-62.

10. Bunn HE, Forget BG, Ramney HM. Human hemoglobins variants. In: Smith LH, editor. Human Hemoglobin. Philadelphia: W. B. Saunders Co; 1977. p. 225-6.

11. Rao S, Kar R, Gupta SK, Chopra A, Saxena R. Spectrum of hemoglobinopathies diagnosed by cation exchange-HPLC and modulating effects of nutritional deficiency anaemias from north India. Indian J Med Res 2010;132:513-9.

12. Zeng $\mathrm{Y}$, Huang $\mathrm{S}$, Ren $\mathrm{S}$, Li H. Identification of $\mathrm{Hb}$ D-Punjab Gene: Application of DNA amplification in the study of abnormal haemoglobins. Am J Hum Genet 1989;44:886-9.

13. Weatherall DJ. Pathophysiology of $\beta$-thalassemia. Baillieres Clin Haematol 1998;11:127-46.

14. Sachdev R, Dam AR, Tyagi G. Detection of $\mathrm{Hb}$ variants and hemoglobinopathies in Indian population using HPCL: Report of 2600 cases. Indian J Pathol Microbiol 2010;53:57-62.

15. Wajcman H, Prehu C, Bardakdjian-Michau J, Prome D, Rious J, Godart C, et al. Abnormal hemoglobins: Laboratory methods. Hemoglobin 2001;25:169-81.

16. Bravo-Urquiola M, Arends A, Montilla S, Velasquez D, Garcha G,
Alvarez $\mathrm{M}$, et al. Advantage in the use of high performance chromatography technique for screening hemoglobinopathies in Venezuela. Invest Clin 2004;45:309-15.

17. Moorchune N, Phillip J, Sarkar RS, Prasad R, Dutta V. Is high pressure liquid chromatography an effective screening tool for characterization of molecular defects in hemoglobinopathies? Indian J Pathol Microbiol 2013;56:36-9

18. Meena LP, Kumar K, Singh VK, Bharti A, Rahman SKH, Tripathi K. Study of mutations in $\beta$-Thalassemia trait among blood donors in eastern Uttar Pradesh. J Clin Diagn Res 2013;7:1394-6.

19. Madan N, Sharma S, Sood SK, Colah R, Bhatia LM. Frequency of $\beta$-thalassemia trait and other hemoglobinopathies in northern and western Indian. Indian J Hum Genet 2010;16:16-25.

20. Jain BB, Roy RN, Ghosh S, Ghosh T, Banerjee, Bhattacharya SK. Screening for thalassemia and other hemoglobinopathies in a tertiary care hospital of West Bengal: Implication for population screening. Indian J Public Health 2012;56:297-300.

21. Baig SM, Azar A, Hassan H, Baig JM, Aslam M, Ud Din MA, et al. Prenatal diagnosis of $\beta$-Thalassemia in Southern Punjab, Pakistan. Prenat Diagn 2006;26:903-5

22. Meena VK, Kumar K, Meena LP, Bharti A, Kumar A. Screening for hemoglobinopathies in blood donors from Eastern Uttar Pradesh. Natl J Med Res 2012;2:366-8.

23. Sukumaran PK, Master HR. The distribution of abnormal haemoglobins in the Indian population. In: Sanghvi LD, Balkrishnan V, Bhatia HM, Sukumaran PK, Undevia JV, editors. Human population genetics in India. Mumbai: Brient Longman; 1974. p. 91-111.

24. Wajcman $\mathrm{H}$, Maradkhani K. Abnormal haemoglobins: Detection and characterization. Indian J Med Res 2011;134:538-46.

25. Modell B, Bulyzhenkov V. Distribution and control of genetic disorders. World Health Stat Q 1988;41:209-18.

26. Cao A, Rastelli MC, Gallanello R. Control of $\beta$-thalassemia by carrier screening genetic counseling and prenatal diagnosis: The Sardinian experience. Ciba Found Symp 1996;197:137-51.

27. Ginsberg G, Tulchinsky T, Filon D, Goldfarb A, Abramov L, Rachmilevitz EA. Cost-benefit analysis of a national Thalassemia prevention programme in Israel. J Med Screen 1998;5:120-6.

28. Leung KY, Lee CP, Tang MH, Lau ET, Ng LK, Lee YP, et al. Cost effectiveness of prenatal screening for Thalassemia in Hong Kong. Prenat Diagn 2004;24:899-907.

How to cite this article: Kumar R, Gupta S, Jindal A, Kakkar S, Kaur A. Screening of $\beta$-thalassemia trait and other hemoglobinopathies among blood donors in Punjab. Int J Med Public Health 2015;5:106-9. Source of Support: Nil, Conflict of Interest: None declared. 